\title{
顏面失行と頭頂, 後頭葉症侯群
}

\author{
Facial Apraxia and Parieto-Occipital Syndrom
}

\author{
國立國府鄫病院 精种 科 \\ 厚生技官醫學士。菅、野重道 \\ Kanno Shigemichi
}

\section{1. 緒 論}

顔面失行は既に Jackson や Wernicke に依 つて觀察, 報告され又 Liepmann の失行症の 最初の詳細な分析例に於ても重篤な顔面失行が 見ら就た。其後觀察された顔面失行に於ても大 多數のものは主として重篤な運動失語又は構音 障碍の際に認められている。然し例外的な少數 の症例飞於て運動失語以外の失語症例飞於て郎 万 Goldstein, Bonvicini, Sittig は夫љ健忘失 語或はそれに近い失語症例に於て顔面失行を觀 察し, 又他の肢體の失行症を伴は婸合に「弧 立的顔面失行」と呼ばれ, Lewandowsky, Pineas, Schilderは夫ょ閉瞼の失行症を, Lange, Pussep u. Lewin 等は喂下の失行症を報告し ている。以上顔面失行を惹起する病籰として主 に前頭葉殊に Broca の中樞或は其近緣が問題 にされている。然し Kleist は腦創傷者て於け る經驗から前頭葉性の顔面失行の他に緣上回轉 の病篭によつて惹起される顔面失行の存在を主 張し, 叉 Lange \& Kroll の症例支引用して 緣上回轉の病篭に依つて ideokinetische Gesichtsapraxie が現われ得ると述べている。

私は構成失行, 手指認識障碍及び左右障碍等 の頭頂葉一後頭葉接衝領域症候群と後頭葉症候 群と共に顔面失行を示した 症例を觀察したの で，この自家經驗例を報告し，從來言はれてい る前頭葉と共に, 頭頂葉近緣の障碍によつて顔 面失行の惹起されることを推定しその顔面失行 の樣相を分析してみたいと思う。

\section{2. 症例}

满50歳 女 女中 家族歷 父 76 歳肺炎飞て死亡，母50歳胃腸疾患にて死亡。同 胞10名中兄 1名60歳結核死, 姉 1名57歳腦溢血
死, 妹 1名41藏心臟病死, 妹 1名17歳腸チフス 死。既往歷 敕年前, 腎臟病に惟患したが數ケ 月で輕快。性病は否定し, 酒・煙草は嗜まな い。

呚育は小學校 4 年修了で，勉强が嫌いで県面 目に通學しなかつたという。其後處及に女中奉 公をなし, 結婚して 3 兒を擧げたが, 離婚し現 在全く夫，子供と連絡がない。

發病經過 昭和 23 年10月頃上り某氏宅に女中 として住み込んでいたが, 昭和24年10月頃月經 閉止し其頃より頭痛を訴人, 又金の勘定を間違 える。又品物の名を忘れて指示したり，お茶を つく時江茶椀の外についだりする。漬物や果物 を切る時見當違いの所を切る。其後次第にふさ ぎ込んで口數が少くなり，山の中の靜かな所へ 行きたい等と云う。而し11月中旬兄の家に來た が，兄も姉多異常に氣付かなかつた。昭和25年 1月1日再び休暇で兄の家に來たが，それまで 明朗だつたのが，何一つせずぼんやりして話も せす布團に入つて寢ている。又男の子を峬ちゃ ん，姉を奥樣と呼んだり，箸をとると云うのを 釘をとる等と言う。物の名志忘てて「あれが 「何が」「何を何して」等と云う。1月4日或 立國府臺病院外來受䛦。同月14日臺所で轉倒, 意識障碍はなかつたが，右上下肢が不自由とな り箸が持てなくなつだ。然し 2 日位の間に速か に回復した。同月16日，國立或府营病院精神科 入院。

入院後の經過 心音, 肺野江特記すべき所見 なく、動脈硬化も著明でない。血壓: 最高115最 低60。尿蛋白隍性。䁩脊髓液所見: 水㥞透明, Nonne, Pandy 何れ \&陰性, 細胞數 $8 / 3$, Wassermann 反應除性, Mastix, 高田荒反應何れ 


$$
-76 \div(1168)
$$

も正常曲線を示す。血清 Wassermann 及び村

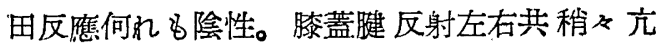
進, 腹壁反射缺如。其他病的反射を認めない。 又腦资髓神經飞麻痺乃至不全麻痺を認めない。 表在感覺正常。㮩孔左右共輕度不正圓形, 稍火 縮小，對光反應稍及緩慢，調節交軲反應正常。 份, 當院眼科《低賴して眼底其他眼科的憸診を 行つたが，硝子體の輕度の混濁の五る他著明な 異常は認められなかつた。視力る後記する樣な 神經病學的諸症狀の爲詳細な測定は不可能であ つたが， $6 \mathrm{~m} の$ 距離でボタン，腕時計等を認知 することが出來，著明な障碍㤌ないと思はれ る。粗大力略正常, Romberg 陰性。Diadochokinesis，手指一鼻尖，手指一手指及び鉒蓋足 踵試驗何れ拙劣。

入院後は日常の立居，振舜，臥床，起立，歩 行, 脫衣, 着衣等何れも動作稍々緩慢だが特別 の異常を認めない。病室にてはむしろ無口，無 䉆。㭙泀同室の患者がうるさいと云つて怒る。 精神的には病識不全, 輕展の自發性低下, 時に emotionelle Inkontinen $z$ 。談話は略々異常な く逐行されるが, 語彙貧弱, 思路漇滞, 判斷力 不良にして簡單な事柄の領取にば殆ど異常を認 めないが，複雜な問題になると不良である。

\section{䆠 症 狀}

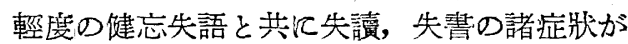
認られる。これ范一括表示すれば第1表の如 くである。

管 1 表

\begin{tabular}{|c|c|c|c|c|c|c|c|c|c|}
\hline 自 & $\overrightarrow{\overline{⿳ 亠 二 口}}$ & 惨 & 錹 & 㢁 & 模 & 㸓 & 自 & 㫮 & 窵 \\
\hline 㹲 & 語 & & & 列 & 做 & & 發 & & \\
\hline$\overline{\overline{\bar{B}}}$ & 理 & & & 言 & $\overrightarrow{\bar{n}}$ & & 書 & & \\
\hline 語 & 解 & 語 & 語 & 話 & 話 & 蜀 & 宗 & 取 & 字: \\
\hline- & - & \pm & $\begin{array}{l}ナ \\
シ\end{array}$ & \pm & - & + & + & + & + \\
\hline
\end{tabular}

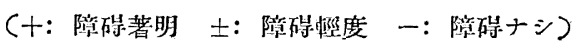

輕度の自體部位認識障碍, 左右障碍, 手指認 識障碍, 棈成失行, 計算不能症, 立體感覺障碍, 視覺運動性眼球震燙の減弱が認めれる。(第2表)
第 2 表

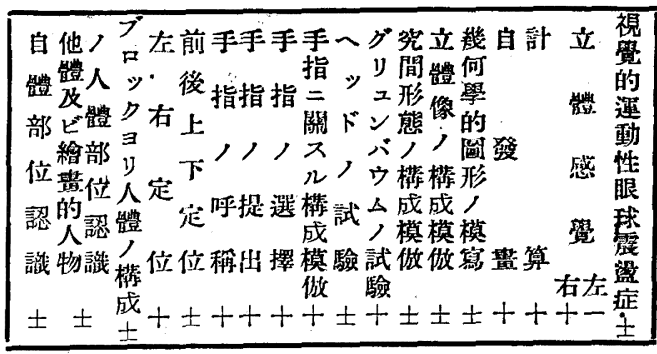

顔面失行は別として其他の要素的運動, 再歸 運動, 對象物の操作, 複雜した操作等に著明な 失行症狀はない。又色彩認識障碍, 視學的認識 障碍, 同時認識障碍, 方向定位の障碍が認めら 肌る。（第 3 表）

第 3 表

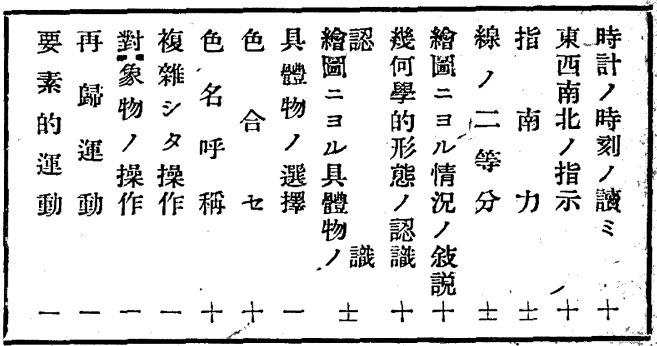

顔面失行は ideokinetishe Gesihtsapraxie の傾向が著しく左右の差異は認められない。 （第 4表）郎ち日常の飲食, 箬の使用, 食事時 の口腔览下運動江異常を認めす，又假性延髓球 麻痺性現象を認めない。笑, 怒, 涕泣等江伴う 表情運動も尋常である。然ると命令又仗模倣に 於て顔面動作は種々の困難を露呈する。郎方額 飞駺を寄せる，閉眼は命令，模倣共略々可能な るも封に懙起困難, 或いは瞼裂を逆開大して 了う。片眼の閉鎖は常に兩眼共閉鎖する。上下 の膽梘は命令, 模倣共略及逐行し得るが長い膽

$$
\text { 第 } 4 \text { 表 }
$$

\begin{tabular}{|c|c|c|c|c|c|c|c|c|c|c|}
\hline $\begin{array}{l}\text { 額 } \\
= \\
\text { 皺 } \\
\text { 尹 } \\
\text { 寄 } \\
\text { セ }\end{array}$ & 閉 & 眼 & 胧 & 捉 & 示 & $\begin{array}{c}\text { 息 } \\
\text { F } \\
\text { 咋 }\end{array}$ & $\begin{array}{l}\text { 兩 } \\
\text { 唇 } \\
\Rightarrow \\
\triangleq \\
\text { ボ } \\
x\end{array}$ & $\begin{array}{l}\text { 煩 } \\
\exists \\
7 \\
\text { D } \\
\overline{7} \\
\nabla\end{array}$ & $\begin{array}{l}\text { 咀 } \\
\text { 哴 } \\
\text { 造 } \\
\text { 動 } \\
\text { 模 }\end{array}$ & 弦 \\
\hline$\pi$ & 眼 & 銷 & 視 & 出 & ス & $\pi$ & U & z & 做 & 喛 \\
\hline \pm & \pm & + & \pm & + & + & + & + & + & + & - \\
\hline
\end{tabular}


視恃困難，時に頭部を趈轉するのみで膽視の現 れないことがある。左右の膽悓についても同樣 であるが，左右定位障碍のため更に困難とな る。舌の提出は命令，模倣共に口を半開するの み。マツチに點した火を吹き消すことは誤りな 〈出來るのに，對象なく息を口から吹き出すこ とは困離であり，又兩唇をつぼめてつき出すこ とも命令, 模倣共に不可能である。顂をふくら ますことも命令, 模倣共に不可能。食物なしに 明嘌運動苍命令又は模倣させると全く困離とな る。發咳は命令, 模倣共可能である。

以上の顔面失行々頭頂, 後頭葉症候群は其後 殆んビ不變の狀態を續け，10ケ月の入院後退院 した。

\section{3. 總括並びに考案}

頭頂, 後頭葉症候群と共に顔面失行を示した 症例を報告した。郎ち構成失行, 手指認識障 碍, 左右定位障碍, 計算不能症, 失書, 輕監の 健忘失語, 失讀, 色彩認識障碍, 同時認識障碍 等の多彩な症候を呈すると共に，顔面失行を示 し，その顔面失行は殊に顔面下部に著明で为つ た。以上の症候群の診斷として脑軟化, 或いは 腦血管性疾患を推定した。

從來顔面失行は緒言に述べたように殆んど運 動失語又は構音障碍の際に認められ, 他の失語 に顔面失行が觀察されることは稀有であるとさ れている。我國に於ても井村氏は23例の失語症 者の雚察に於て運動失語及び感覺失語の 2 例の 失語症者に顔面失行を觀察し, 顔面失行の成立 を語音の習得過程に關與する「視鱟的一運動感 學的機能」の崩潰と考え，この因子は「䈯覺的 一運動感覺的機能」と共に語音の理解及び表出 に副炊的ながら關與しており，輕症の失語症で は後者が侵されるが，前者は份健存して代償的 に働き, 重症の失語症では网者共漳碍されて 顔面失行が招來される。この悓覺的因子は言語 の理解，表現兩側面に關與するのであるから運 動失語以外の他の失語症顔型飞も顔面失行が發 現することも當然であると說明している。本症 例には運動及び感學失語は存在せす, 輕度の健 忘失語が存するのみであり，命令及び模倣時隹
於ける顔面失行のみが著明であつて, 日常行嫣 及び具體的事態に於いては殆んど顔面失行は明 瞭には出現しないことは單に井村氏の云るょう な感覺一運動性機能の障碍によつて說明し得る かどうかは疑問であると思はれる。又，Kleist は症例に依る裏づけはないが，前頭葉性の顔面 失行の他治上回轉江病䆛を有する顔面失行の 存在を主張し，その特徵は「運動の混錯」 $\mathrm{Be}$ wegungsverwechslung を示すことであると云 う。本症例仿於ては然しこのような症狀も明瞭 でなかつた。Kroll は自家經驗例より左緣上回 轉の障碍によつて顔面筋の失行症の發生を主張 しているが，該例の失行症は全身汇亘り，頭 部，顏面筋のみならす四肢にも及び，特に運動 及び姿態の模倣が著しく困離であつた。本症例 ではこのような廣範な失行症は存在せす，失行 症は顔面に著しく，それと共に構成失行が存在 した。

郎ち本症例に於ける顔面失行の發生は後頭葉 病筐により失行症の生することを否定して考え るならば頭頂葉殊に緣上回轉週傻の病籄を假定 することが出來ると思う。健忘失語, 棈成失行 其他の所謂 Gerstmann 氏症候群を發生せ乙わ ている頭頂一後頭接衝領境の病窞から顔面失行 も亦生じたものと考えられる。顔面行爲は通常 の狹い意味での構成行䉆と云うことは出來な

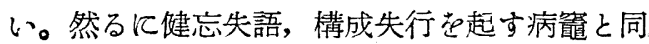
じ或いは近緣の病筧によつて顔面失行が同㭙に 見られ得ることを本症例は推定するるのであ る。その顔面失行は Liepmann $\odot$ ideokinetische Apraxie の傾向が强く, 殊江模倣, 命 令に依る行爲に於て著しく又 Bonvicini の云 う如く顔面下部，口，頓，舌の諸筋群郎ち言語 筋群に著明で岕つた。そしてその顔面行爲に於 て部分的, 不完全な行爲示して患者は平然と している。然も日常の行爲或は具體的對象に對 する行爲汇於ては著しい障碍はなく, 模倣, 命 令几依る顔面行䉆汸於て急激㵔しい失行症を 示す。この「頭頂葉性顔面失行」の發生機轉に ついて次浡考按を述べてたい。

Liepman の「行雼の企圖」換言すれば「運 


$$
-78-(1170)
$$

動形式」は Kleist によれば時間並びに空間の 二次元性を有し, 從つて企圆性失行症は理諭的 には運動形式に於ける時間錯䛊によるものと， 空間錯誤によるものとの二つに區别出來る。そ して純粹に空間錯詔のみに基く企圆性失行症は 師古構成失行症であり, 本症例㳊於ける構成失 行症る亦この上うに理解される。Straussは更 水企圖性失行症は

1. 空間錯誤 (構成失行症の要素)

2. 時間錯誤

a. 個々の運動自體の進行の時間錯誤乃至 はその發現の逮延（企圖運動性失行症 の要素)

b. 個ぬの運動の順序に於ける時間的錯愦 を含むるのであるとした。本症例の如き顔面失 行は, この空間錯誤によるるのでるなく, 叉個 々の運動の順序に於ける時間的錯䛊によるるの でもない。2，a，の障碍のみが問題となる。 節ち個及の運動自體の隻行の時間錯誤乃至はそ の發現の遲延が問題となる。然し本症例の顔面 失行は單なる個々の顔面運動乃至行䉆の時間錯 誤でもなく，その發現の遲延でもない。それは 模做, 命令による行䉆の完全な逐行の障碍であ $b$, 行爲の一部趸逐行し或いは不完全に逐行し て完全な逐行に代えていることである。從つて 他の身體部位に於的る企圖運動性失行症と稍々 その樣相を異にしている。それは顔面運動乃至 行篇の他の身體部位に於ける行爲との相違にそ の特性が求められねばならない。即古顔面行爲 は Jackson の法則に於ける手殊飞手指沉次い で身䯣中で最も智的な部分であると共に表情運 動として行爲に於ける感情的因子と最飞密接に 結合している。この特性の中に本患者の顔面失 行の特徵は上く理解されると思仗れる。郎ち日 常行第, 具體的對象飞對する行爲に於てはその 對象及び對人と患者とをとりまく具體的事態て 於いて患者の中に自然な感情的な流れが生じ得 るが，模倣，命令時の具體を離れた高次の抽象 的概念的事態に於てはこの感情的な流れが患者 の中に生することが出來す，この行爲に於ける 感情的因子 Affektives Element の脫落によ
つて, 行篇の逐行が妨げられ, 中断され, 不完 全なるのとなる。Apraktognosie, Agnosopraxie 等の提樣によつて行临と認識との全一體 芷强調する Grünbaum, Kroll, 秋元等の失行

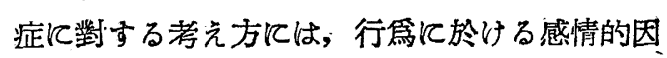
子の考虑がなされていないが，言語に於いて感 性言語 affektive Sprachè, 知性言語 intellektuelle Sprache が區别されるように，行雼は

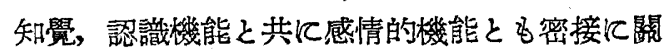
聯し, Jackson の Integration として, 神經 采統は知覺, 運動機能と共飞感情的機能をも統 合した全一體をなするのである。本症例に於け る命令, 模做時に於て顔面失行が急激江㥢惡, 出現するのは單なる知學, 運動機能の障碍では なくして患者の中に發生すべき感情的因子の障 碍て依るこの全一體の解離 Dissoziation とし て理解されるべきであると考えるのである。

\section{4. 結 論}

多彩な頭頂, 後頭領域の症候群々共に健忘失 語に伴つて顔面失行の見られた症例莨報告し， その顔面失行の樣相及び發生機轉について分析 した。それは日常生活及び具體的對象に對する 事態に於ては失行症狀柱明膫でなく, 模倣及び 命令に上る顔面行爲に於て急激に失行症狀が著 明となる。顔面失行と共に構成失行が, 觀察さ れたが, 顔面行爲は通常の狹い意味での構成行 爲ではない。又表情運動として深く感情的因子 と關聯している。この特性の中に本症例の「頭 頂葉性顔面失行」の特徽はその說明が求められ る。郎ち日常行篇, 具體的な對象记對する行爲 に於てはその對象及び對人とに齿して, 自然な 感情的流れが患者の中生じるが, 模做, 命令 時の具體を離れた高次の抽象的事態に於ては此 感情的流れが生することが出來す, 行霨に於け る感情的因子の脱落によつて行爲の逐行が妨害 され不完全なものとなる。行爲は知學, 認識機 能と共に感情的機能と夕密接儿關聯し, 神經系 統はこれ等諸要素を統合した全一體をなするの であり，本症例の顔面失行は患者の中潑生す べ感情的因子の障碍に依つて生じたこの全一 體の解離として理解さるべきである。 
この症例は昭和25年 3 月 4 日干葉醫大に於て 開催された東京精神神經學會に於て「顔面失行 と Gerstmann 症候群」と題して報告した。

擱筆するに當り御懇切なる御指導並に御校閲 を賜わつた本擧神經科久保喜代二教授に梁甚な る謝意を表します。又或立國府臺病院精神科醫 長高木四郎博士の御助言御援助飞對し感謝致し ます。

$$
\text { 主 要 交 献 }
$$

(1) 秋元波留夫: 夹行掟, 金原谪店 (昭10)

(2) 井村恒郎: 精种經誌, 44巻 (昭15)

(3) 石橋俊贷: 神經誌, 38卷 (昭9)

(4) 秋元波留夫: 种經誌, 35 卷 (炤7)

(5) Lange, J.,: Handbuch \& Neurologie II (1936)

(6) Kleist, K.,: Gehirnpathologie (1934)

(7) Kroll, M.,: Die Neuropathologischen Syndrome (1929)

(8) 平澤興, 小池上春芳: 大腦皮所下於ける中栍 問題, 山雅房 (昭18)

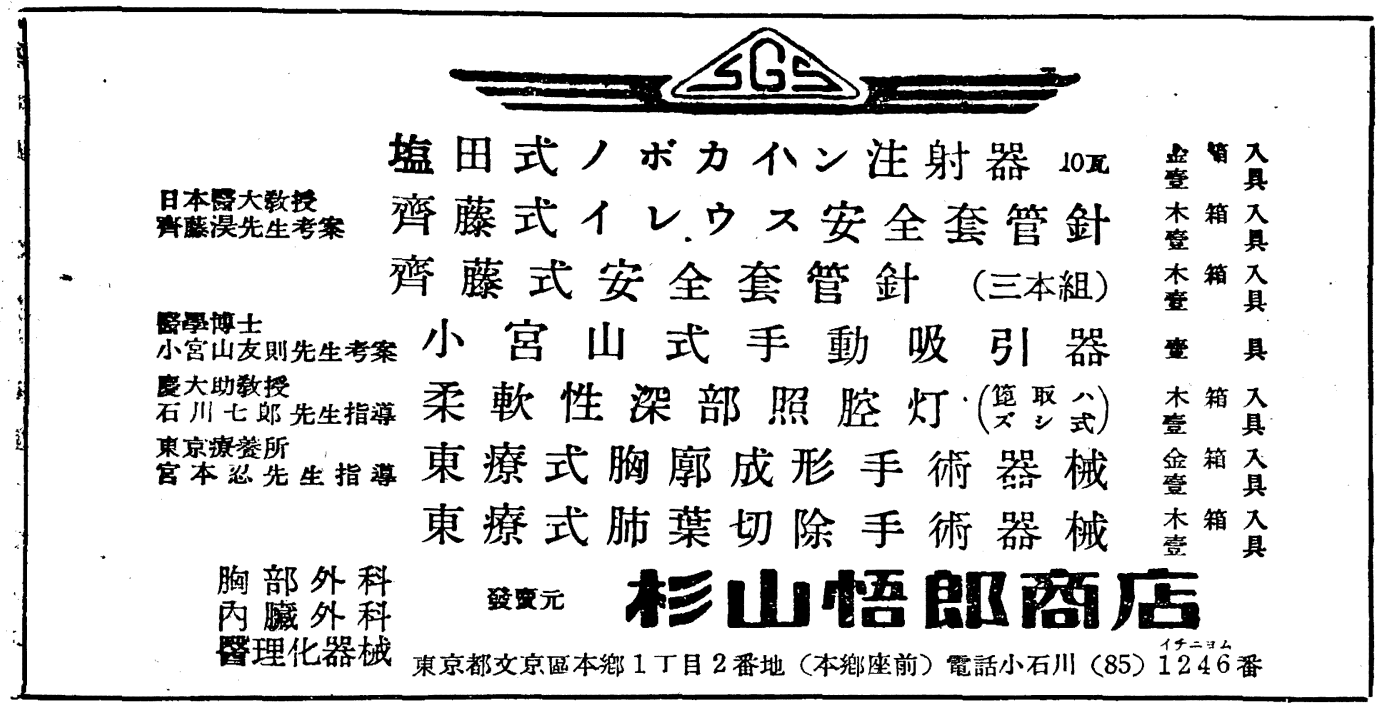

